\title{
Effects of 7-ketocholesterol on the activity of endothelial poly(ADP-ribose) polymerase and on endothelium-dependent relaxant function
}

\author{
LEVENTE KISS $^{1}$, MIN CHEN ${ }^{2}$, DOMOKOS GERO ${ }^{3}$, KATALIN MÓDIS ${ }^{3}$, \\ ZSOMBOR LACZA ${ }^{1}$ and CSABA SZABÓ ${ }^{3,4}$
}

\author{
${ }^{1}$ Department of Human Physiology and Clinical Experimental Research, Semmelweis University, Ülloi út 78/A, \\ Budapest 1082, Hungary; ${ }^{2}$ Inotek Pharmaceuticals Corporation, Suite 419E, 100 Cummings Center, Beverly, MA 01915; \\ ${ }^{3}$ Department of Surgery, University of Medicine and Dentistry of New Jersey, Newark, NJ 07103, USA; \\ ${ }^{4}$ CellScreen Applied Research Center, Budapest, Ulloi ut 93, Hungary
}

Received June 14, 2006; Accepted August 28, 2006

\begin{abstract}
Oxidative and nitrosative stress play an important role in the development of endothelial vascular dysfunction during early atherosclerosis. Oxidative stress activates the nuclear enzyme poly(ADP-ribose) polymerase (PARP) in endothelial cells. In patients with atherosclerosis the level of oxidized LDL in the plasma is elevated. In oxidized LDL various oxysterols have been identified, such as 7ketocholesterol $(7 \mathrm{~K}) .7 \mathrm{~K}$ has been shown to induce PARP activation in microglial cells. The aim of the current study was to clarify the effects of $7 \mathrm{~K}$ on the activity of endothelial PARP and on the endothelium-dependent relaxant function of blood vessels. We treated human umbilical vein endothelial (HUVEC) cells with $2-16 \mu \mathrm{g} / \mathrm{ml} 7 \mathrm{~K}$ as well as vascular rings harvested from BALB/c mouse thoracic aorta with $90 \mu \mathrm{g} / \mathrm{ml}$ $7 \mathrm{~K}$ for $2 \mathrm{~h}$. A group of mice was treated with $7 \mathrm{~K}$ subcutaneously for 1 week $(10 \mathrm{mg} / \mathrm{kg} /$ day $)$. We also conducted in vitro and in vivo experiments using pretreatment with buthionine sulphoximine (BSO), a glutathione-lowering agent. The activity of PARP was calculated by measurement of tritiated NAD incorporation. The activity of PARP increased significantly in 7K-treated HUVEC cells. After BSO pretreatment, this increase was higher. Isolated vascular rings demonstrated no change in endothelium-dependent relaxant function after $2 \mathrm{~h}$ of incubation with $7 \mathrm{~K}$, even after BSO pretreatment. In vivo treatment with $7 \mathrm{~K}$ for 1 week had no effect on the relaxant function. Our experimental results suggest that although 7-ketocholesterol can activate PARP enzyme in endothelial cells, it is not sufficient on its own to cause impairment in the endothelium-dependent vascular reactivity.
\end{abstract}

Correspondence to: Professor Csaba Szabó, Department of Surgery, University of Medicine and Dentistry of New Jersey, 185 South Orange Avenue, University Heights, Newark, NJ 07103-2714, USA

E-mail: szabocsaba@aol.com

Key words: atherosclerosis, endothelial dysfunction, poly(ADP-ribose) polymerase, 7-ketocholesterol

\section{Introduction}

Oxidative and nitrosative stress play an important role in the pathogenesis of atherosclerosis $(1,2)$. Elevated levels of oxidative DNA damage have been shown in atherosclerotic plaques (3). Oxidative DNA damage activates the PARP enzyme. PARP is an abundant nuclear enzyme, whose overactivation promotes cell death (4). PARP also plays a role in neointima formation (5).

Low density lipoproteins are the major vehicles transporting cholesterols in plasma. In patients with atherosclerosis the LDL levels are usually high and the oxidation of these particles is considered to be a major factor in their atherogenicity (6). One of the main oxysterols in oxidized LDL (oxLDL) is 7-ketocholesterol (7). 7-Ketocholesterol (7K) was shown to inhibit arterial endothelium-dependent relaxation in rabbit aortas (8) and was reported to activate PARP in microglial cells (9), although the latter occurs at very high $7 \mathrm{~K}$ concentrations (10).

PARP activation may play a role in the pathogenesis of atherosclerosis, as inhibition improves the endothelial function of apoE-deficient mice (11). In the context of examining the potential role of PARP and $7 \mathrm{~K}$ in the early stage of atherosclerosis, here we investigated whether $7 \mathrm{~K}$ induces PARPactivation in endothelial cells, and we examined its role in the development of endothelial dysfunction.

\section{Materials and methods}

Measurements of PARP activation in HUVEC cells. Human umbilical vein endothelial (HUVEC) cells were plated at a density of 250,000 cells per well in a 12-well plate and grown in M199 media supplemented with $10 \%$ fetal calf serum and $0.03 \mathrm{mg} / \mathrm{ml}$ endothelial cell growth supplement. After $24 \mathrm{~h}$, the media was replaced and the cells were treated with increasing concentrations of $7 \mathrm{~K}(2,4,8,16 \mu \mathrm{g} / \mathrm{ml})$ for $24 \mathrm{~h}$ with or without L-buthionine-( $\mathrm{S}, \mathrm{R})$-sulphoximine (BSO, $1 \mathrm{mM}$ ). In subsequent experiments HUVEC cells were treated with $\mathrm{H}_{2} \mathrm{O}_{2}$ (positive control) or with $20 \mu \mathrm{g} / \mathrm{ml} 7 \mathrm{~K}$ with or without pretreatment with the PARP inhibitor, PJ-34 $(3 \mu \mathrm{M}, 1 \mathrm{~h})$ or the nitric oxide synthase (NOS) inhibitor, $N$-nitro-L-arginine methyl ester (L-NAME, $3 \mathrm{mM}, 1 \mathrm{~h}$ ). For 
the measurement of cellular PARP activity $(12,13)$, the media was removed and replaced with $0.5 \mathrm{ml} \mathrm{N}-2$ hydroxyethylpiperazine-N'-2'-ethanesulfonic acid ( $\mathrm{pH} 7.5)$ containing $0.01 \%$ digitonin and $3 \mathrm{H}-\mathrm{NAD}(0.5 \mu \mathrm{Ci} / \mathrm{ml})$, and the cells were incubated for $20 \mathrm{~min}$ at $37^{\circ} \mathrm{C}$. The cells were then scraped from the wells and placed in Eppendorf tubes containing $200 \mu \mathrm{l}$ ice-cold $50 \%$ trichloroacetic acid (TCA) $(\mathrm{w} / \mathrm{v})$. The tubes were then placed at $4^{\circ} \mathrm{C}$. After $4 \mathrm{~h}$, the tubes were centrifuged at $1800 \mathrm{x}$ g for $10 \mathrm{~min}$ and the supernatant removed. The pellet was washed twice with $500 \mu 1$ ice-cold $5 \%$ TCA. The pellet was solubilized in $250 \mu \mathrm{l} \mathrm{NaOH}(0.1 \mathrm{M})$ containing $2 \%$ sodium dodecyl sulfate overnight at $37^{\circ} \mathrm{C}$. The PARP activity was then determined by measuring the radioactivity incorporated using a Wallac scintillation counter (Wallac, Turku, Finland). The solubilized protein $(250 \mu \mathrm{l})$ was mixed with $5 \mathrm{ml}$ scintillant (ScintiSafe Plus, Fisher, Pittsburgh, PA, USA) before being counted for $10 \mathrm{~min}$. Results are expressed as a percentage of the PARP activity observed in untreated cells. Cell viability was measured by the 3-[4, 5-dimethylthiazol-2-yl]-2, 5-diphenyltetrazolium bromide assay and was unaffected by the pharmacological inhibitors used.

Measurement of isometric force in aortic rings of mice. $\mathrm{BALB} / \mathrm{c}$ mice were treated for 1 week with $7-\mathrm{K}$ or vehicle applied subcutaneously at a daily dose of $10 \mathrm{mg} / \mathrm{kg}$. The method to determine endothelium-dependent vascular relaxation in thoracic aortic rings from mice was described previously (14). Briefly, the thoracic aorta was cleared from periadventitial fat and cut into $3 \mathrm{~mm}$-width rings using an operation microscope, mounted in organ baths filled with warmed $\left(37^{\circ} \mathrm{C}\right)$ and oxygenated $\left(95 \% \mathrm{O}_{2}, 5 \% \mathrm{CO}_{2}\right)$ Krebs' solution $\left(\mathrm{CaCl}_{2}, 1.5 \mathrm{mM} ; \mathrm{MgSO}_{4}, 1.2 \mathrm{mM}\right.$; NaCl, $118 \mathrm{mM}$; $\mathrm{NaHCO}_{3}, 14.8 \mathrm{mM}$; KCl, $4.6 \mathrm{mM}$; $\mathrm{NaH}_{2} \mathrm{PO}_{4}, 1.2 \mathrm{mM}$; glucose, $11.1 \mathrm{mM}$ ). Isometric tension was measured with isometric force transducers (HBM, Q11), which were connected to a transducer-amplifier (HBM, MGA II) and recorded on paper (Kipp Zonen, BD300). A tension of $1 \mathrm{~g}$ was applied, and the rings were equilibrated for $60 \mathrm{~min}$. Fresh Krebs was provided at 20 -min intervals. After equilibration the contractile response of arterial rings to a depolarizing solution of a modified Krebs solution enriched in $\mathrm{K}^{+}(124 \mathrm{mM})$ was initially tested to evaluate their functional integrity. For the measurement of endothelial functionality, the rings were precontracted with phenylephrine $\left(10^{-6} \mathrm{M}\right)$ and then doseresponse curves to acetylcholine $\left(10^{-8} \mathrm{M}-10^{-5} \mathrm{M}\right)$ were constructed. Experiments were conducted on 20 rings in each experimental group.

In a separate set of experiments vascular rings were incubated with $7 \mathrm{~K}(90 \mu \mathrm{g} / \mathrm{ml})$ or vehicle for $2 \mathrm{~h}$, followed by the determination of endothelium-dependent vascular function.

In both sets of experiments subgroups were pretreated with $1 \mathrm{~g} / \mathrm{kg} \mathrm{BSO} / 24 \mathrm{~h}$ for the inhibition of $\gamma$-glutamylcysteine synthetase, thus lowering the antioxidant capacity (15).

The investigation was performed with the approval of the Institutional Animal Care and Use Committee.

Immunohistochemical analysis of PAR. Tissues were fixed in $4 \%$ buffered formalin and paraffin sections were prepared.

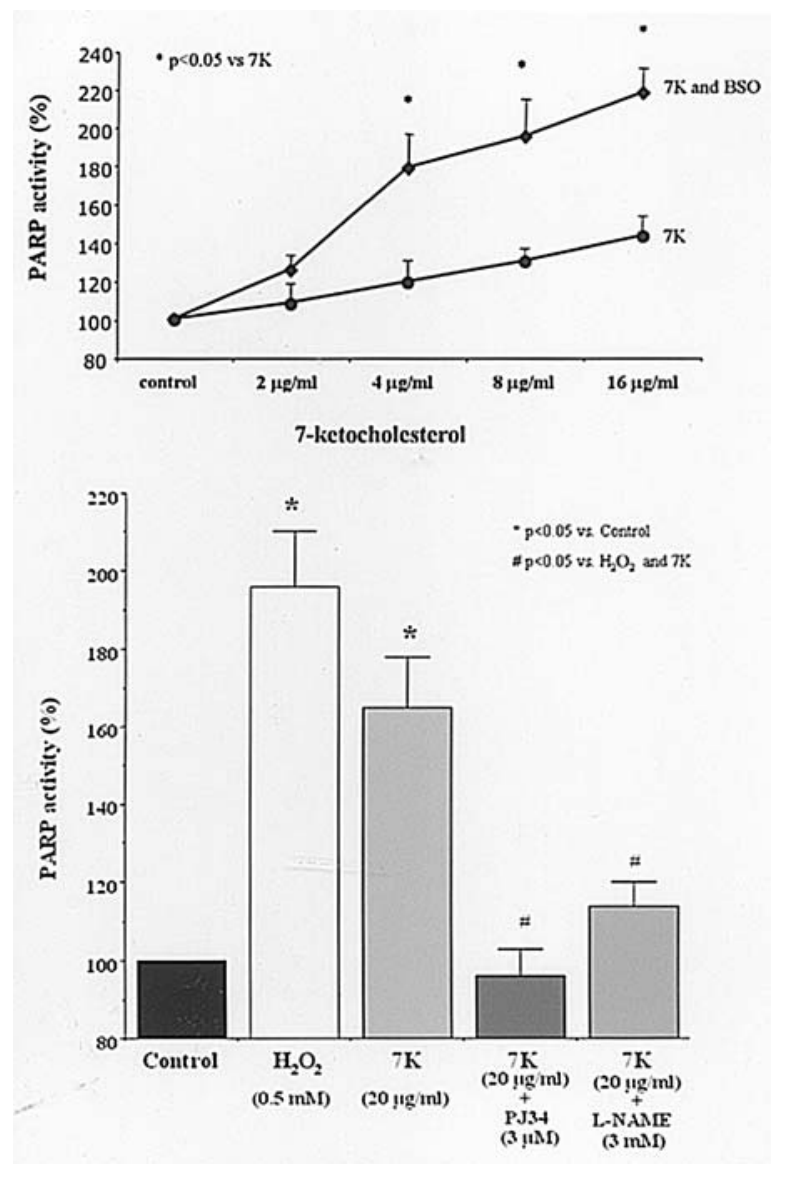

Figure 1.7-Ketocholesterol treatment activates PARP in HUVEC cells in a dose-dependent manner. Further analysis of this effect shows that BSO pretreatment augments this activation suggesting an oxidant effect of $7 \mathrm{~K}$ (upper panel). The degree of PARP activation by $7 \mathrm{~K}$ is comparable to the degree elicited by $\mathrm{H}_{2} \mathrm{O}_{2}$. 7K-induced PARP activation is blocked by PARP inhibitor PJ34 and the non-isoform-selective NOS inhibitor, L-NAME (lower panel). Data represent mean $\pm \mathrm{SD}$.

Sections were treated with $0.6 \% \mathrm{H}_{2} \mathrm{O}_{2}$ in methanol to quench endogenous peroxidase activity and microwaved in $0.2 \mathrm{M}$ citrate buffer ( $\mathrm{pH} 3.0$ ) to retrieve antigenic epitopes. After blocking in $1.5 \%$ normal goat serum, a polyclonal anti-PAR antibody (Calbiochem, San Diego, CA, USA) was applied at a 1:100 dilution. A biotinylated secondary antibody and the ABC method were used to visualize PAR polymers with 3 , 3'-diaminobenzidine-tetrahydrochloride (DAB) and $\mathrm{H}_{2} \mathrm{O}_{2}$ as substrate (Vector Laboratories, Burlingame, CA, USA). Slides were counterstained with Gill's hematoxyline (Accustain, Sigma Diagnostics, St. Louis, MO, USA).

Statistical analysis. Results are reported as mean \pm SD. Statistical significance between measurements was determined by ANOVA followed by a post hoc Dunnett test. Probability values of $\mathrm{p}<0.05$ were considered significant.

\section{Results}

7-Ketocholesterol activated PARP in a dose-dependent manner. This activation was higher with the pretreatment of 

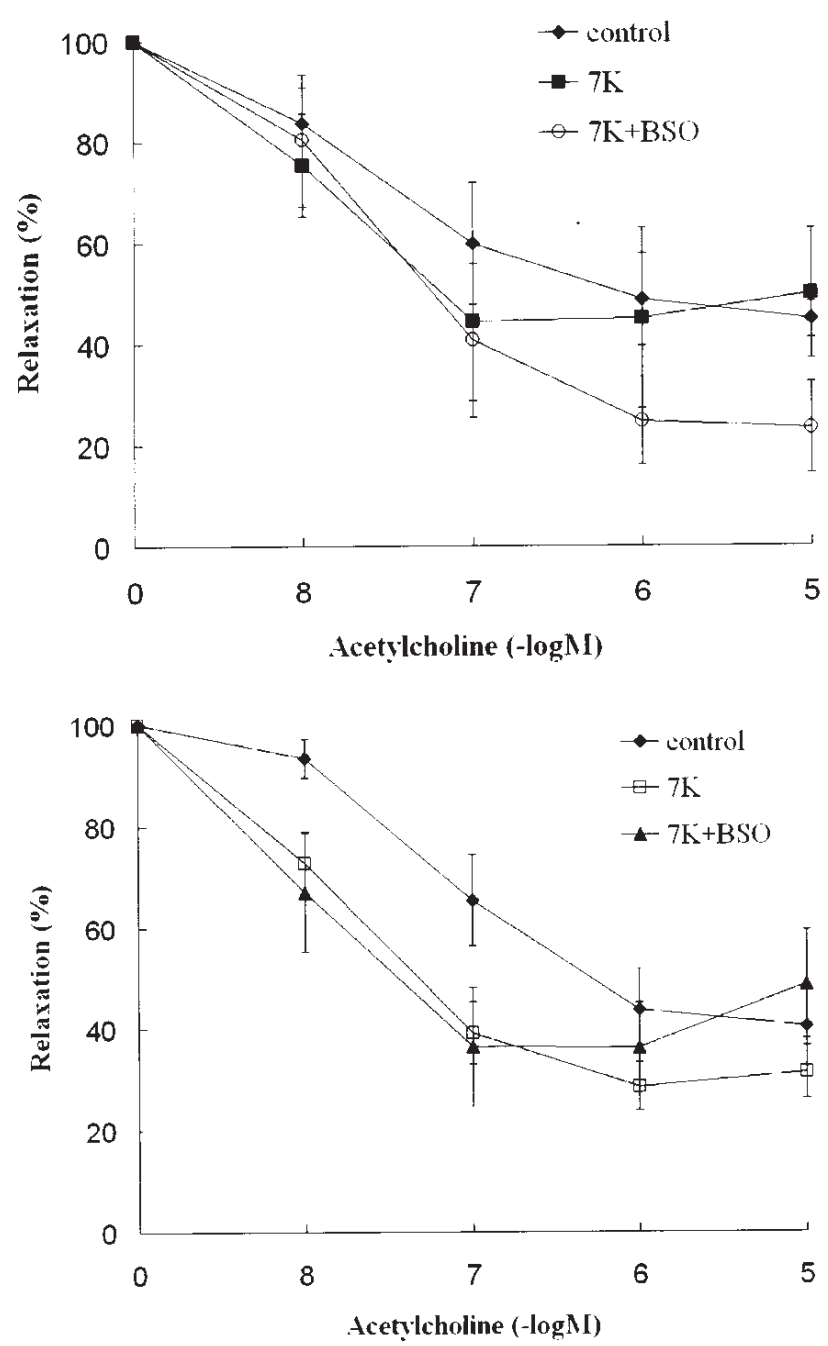

Figure 2. The effect of 7-ketocholesterol treatment on endotheliumdependent vasodilation. Incubation with $90 \mu \mathrm{g} / \mathrm{ml}$ for $2 \mathrm{~h}$ causes no significant dysfunction compared to control (upper panel). Pretreatment of mice with $10 \mathrm{mg} / \mathrm{kg}$ /day $7 \mathrm{~K}$ causes no difference compared to vehicletreated animals (lower panel). Data represent mean $\pm \mathrm{SD}$.

BSO (Fig. 1, upper panel). Further analysis of this activation showed that $7 \mathrm{~K}$ had nearly the same potential in activating PARP as $\mathrm{H}_{2} \mathrm{O}_{2}$, and this activation was able to be blocked by the PARP inhibitor PJ34 and by the non-selective NOSinhibitor L-NAME (Fig. 1, lower panel).

The experiments conducted on the vascular rings showed no difference in Ach-induced relaxations, neither after incubation of rings with $7 \mathrm{~K}$, nor after subcutaneous treatment of mice with $7 \mathrm{~K}$, even in the presence of BSO pretreatment (Fig. 2).

The PARP activity of endothelial cells in the vessel wall showed no significant difference between the groups studied (Fig. 3.).

\section{Discussion}

Several studies have examined the role of oxysterols found in oxLDL in the early pathogenesis of atherosclerosis. The excess concentration of oxysterols was shown to be cytotoxic to endothelial cells inducing apoptosis $(7,16,17)$. Other

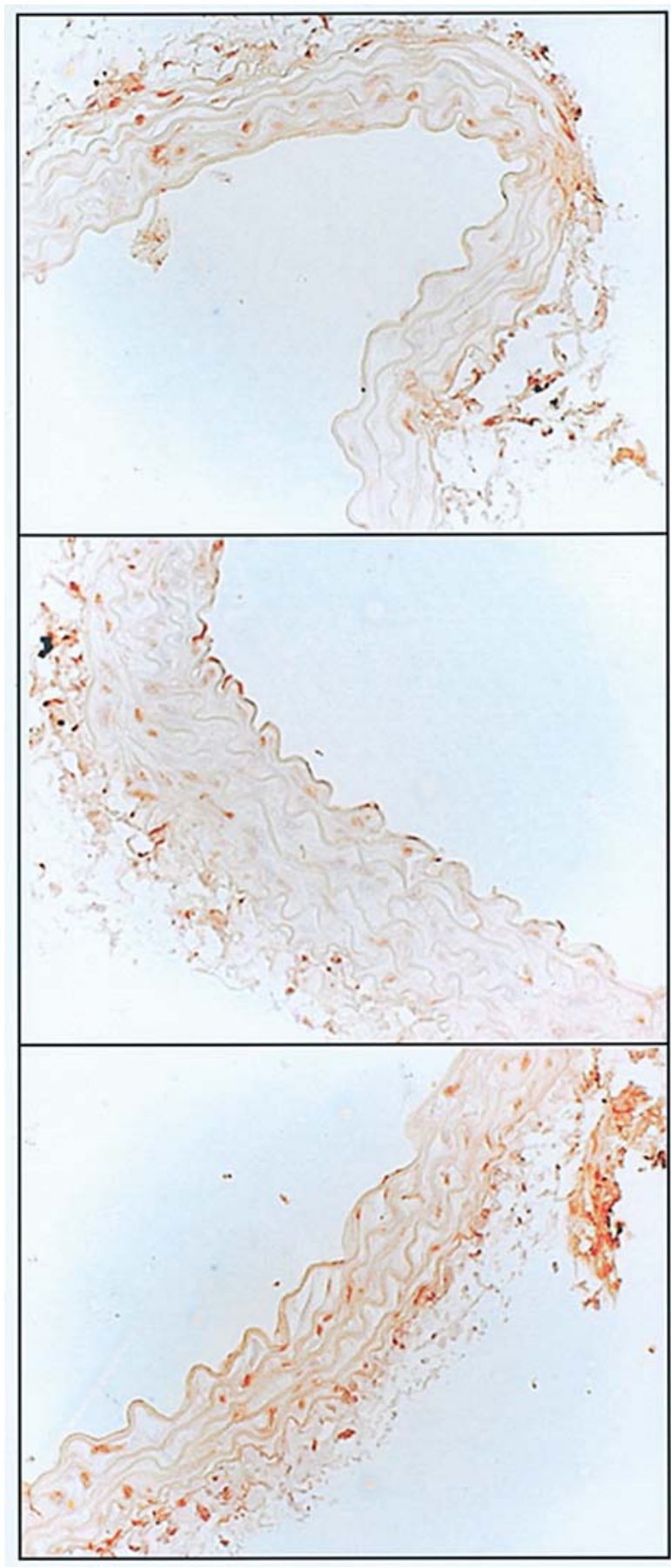

Figure 3. The PARP activity of endothelial cells in the vessel wall shows no significant difference between the groups studied (from top: $7 \mathrm{~K}$ incubation, $7 \mathrm{~K}$ pretreatment, control). Anti-PAR staining (1:100), hematoxylin background.

investigations showed apoptosis of vascular smooth muscle cells after treatment with cholesterol-oxides (18). Mougenot et al measured arterial vasomotor responses related to oxidized LDL and indicated that the major cholesterols contributing to the atherogenic effect were 7-ketocholesterol and 7ßhydroxicholesterol (19). 7K was shown to inhibit arterial endothelial-dependent relaxation in the rabbit aorta (8). Incubating BV-2 microglial cells with $7 \mathrm{~K}$ caused PARPactivation (9). However the possible relation between $7 \mathrm{~K}$ and PARP in the context of endothelial dysfunction has not yet been investigated. 
Poly(ADP-ribose) polymerase-1 (PARP), a monomeric nuclear enzyme present in eukaryotes, is the major isoform of an expanding family of poly(ADP-ribosyl)ating enzymes. The main isoform of the family, PARP-1, functions primarily as a DNA damage sensor. Upon binding to damaged DNA mainly through the second zinc finger domain, PARP-1 forms homodimers and catalyzes the cleavage of $\mathrm{NAD}^{+}$into nicotinamide and ADP-ribose and uses the latter to synthesize branched nucleic acid-like polymers poly(ADP-ribose) covalently attached to nuclear acceptor proteins. The biological role of PARP-1 includes the regulation of DNA repair and maintenance of genomic integrity (20). PARP has been implicated in a variety of pathophysiological processes. PARP overactivation, in response to severe oxidant-induced DNA damage, has been shown to promote cell dysfunction culminating in cell necrosis (21).

Here we demonstrated for the first time that 7-ketocholesterol (the main oxysterol found in oxLDL) is capable of activating PARP in endothelial cells. This activation appears to be related to NOS activity because L-NAME attenuated the effect of $7 \mathrm{~K}$. The phenomenon of PARP activation also appears to be dependent on intracellular oxidative stress, as pretreatment with BSO increased the degree of PARP activation. One likely scenario is that the constitutively produced NO in endothelial cell combines with the superoxide, which, in turn, results in the formation of peroxynitrite, which is a known endogenous trigger of DNA single-strand breakage and PARP activation. In this context, endothelial $\mathrm{NO} /$ peroxynitrite production may result in endothelial dysfunction, which subsequently may damage the endothelial function, and may lead to impaired endothelial NO production later on. Such impaired NO production has previously been demonstrated after $7 \mathrm{~K}$ treatment $(8,22,23)$.

Direct incubation of the rings with $7 \mathrm{~K}$ or subcutaneous treatment with $7 \mathrm{~K}$ did not inhibit endothelial-dependent relaxation in our experimental settings and the endothelial cells in the vessel walls showed no PARP-activation, which could have been due to the effect of the rapid hepatic metabolism of $7 \mathrm{~K}(24,25)$.

To test the effect of $7 \mathrm{~K}$ in a state where the vasculature may become more sensitive to oxidant stress, we utilized BSO pretreatment in mice. In previous studies it was shown that in vascular rings taken from rats which had been pretreated with BSO to deplete endogenous glutathione, there was a significantly more pronounced suppression of the contractility and a significantly more pronounced (near-complete) inhibition of the endothelium-dependent relaxations after peroxynitrite exposure (15). Here we found no evidence that in vivo $7 \mathrm{~K}$ leads to apoptosis and endothelial dysfunction, even after the depletion of glutathione.

Based on the current findings, $7 \mathrm{~K}$ is certainly capable of PARP activation in endothelial cells, but it is unlikely that $7 \mathrm{~K}$, on its own, leads to endothelial dysfunction, although it is possible that local accumulation of $7 \mathrm{~K}$ in plaques may lead to higher, more cytotoxic concentrations. It is probable that $7 \mathrm{~K}$ acts in synergy with other pro-atherosclerotic molecules in the early stage of atherosclerosis.

Data in the literature demonstrate that $7 \mathrm{~K}$ can activate a variety of intracellular pathways such as PKC activation (8), activation of ubiquitin complexes (26), calcium-dependent activation of several pro-apoptotic pathways and also the MEK $\rightarrow$ ERK survival pathway (27), upregulation of the $\mathrm{NAD}(\mathrm{P}) \mathrm{H}$ oxidase homologue Nox-4 (28) or modulation of the $\mathrm{Ca}^{++}$signal and inhibition of eNOS (22). The wide variety of possible effects indicates that $7 \mathrm{~K}$ has numerous targets in the cells of the vascular wall, one of which could be the PARP-pathway, and the combined effects of the activation of these pathways may lead to vascular cell damage and cell death.

Collectively, our results suggest that although the main oxysterol component of oxLDL particles, 7-ketocholesterol, is capable of activating PARP in endothelial cells, it cannot induce endothelial dysfunction alone. It is conceivable that 7ketocholesterols and other oxysterols found in oxLDL together may be responsible for the development of endothelial dysfunction induced by these lipoproteins.

\section{Acknowledgements}

This study was supported by OTKA T49488 and NIH R01 GM060915 to C.S.

\section{References}

1. Daugherty A: Mouse models of atherosclerosis. Am J Med Sci 323: 3-10, 2002.

2. Laursen JB, Somers M, Kurz S, McCann L, Warnholtz A, Freeman BA, Tarpey M, Fukai T and Harrison DG: Endothelial regulation of vasomotion in apoE-deficient mice: implications for interactions between peroxynitrite and tetrahydrobiopterin. Circulation 103: 1282-1288, 2001

3. Martinet W, Knaapen MW, De Meyer GR, Herman AG and Kockx MM: Elevated levels of oxidative DNA damage and DNA repair enzymes in human atherosclerotic plaques. Circulation 106: 927-932, 2002.

4. Virag L and Szabo C: The therapeutic potential of poly(ADPribose) polymerase inhibitors. Pharmacol Rev 54: 375-429, 2002.

5. Zhang C, Yang J and Jennings LK: Attenuation of neointima formation through the inhibition of DNA repair enzyme PARP1 in balloon-injured rat carotid artery. Am J Physiol Heart Circul Physiol 287: 659-666, 2004.

6. Steinberg DS, Parthasarathy S, Carew TE, Khoo JD and Witztum JL: Beyond cholesterol: modifications of low density lipoprotein that increase its atherogenicity. N Engl J Med 320: $915,1989$.

7. Zhou Q, Wasowicz E, Handler B, Fleischer L and Kummerow FA: An excess concentration of oxysterols in the plasma is cytotoxic to cultured endothelial cells. Atherosclerosis 149: 191-197, 2000.

8. Deckert V, Duverneuil L, Poupon S, Monier S, Le Guern N, Lizard G, Masson D and Lagrost L: The impairment of endothelium-dependent arterial relaxation by 7-ketocholesterol is associated with an early activation of protein kinase $\mathrm{C}$. $\mathrm{Br} \mathrm{J}$ Pharmacol 137: 655-662, 2002.

9. Diestel A, Aktas O, Hackel D, Hake I, Meier S, Raine CS, Nitsch R, Zipp F and Ullrich O: Activation of microglial poly(ADP-ribose)-polymerase- 1 by cholesterol breakdown products during neuroinflammation: a link between demyelination and neuronal damage. J Exp Med 198: 1729-1740, 2003.

10. Leoni V, Lutjohann D and Masterman T: Levels of 7-oxocholesterol in cerebrospinal fluid are more than one thousand times lower than reported in multiple sclerosis. J Lipid Res 46: 191-195, 2005.

11. Benko R, Pacher P, Vaslin A, Kollai M and Szabó C: Restoration of the endothelial function in the aortic rings of apolipoprotein $\mathrm{E}$ deficient mice by pharmacological inhibition of the nuclear enzyme poly(ADP-ribose) polymerase. Life Sci 75: 1255-1261, 2004.

12. Soriano FG, Virág L, Jagtap P, Szabó E, Mabley JG, Liaudet L, Marton A, Hoyt DG, Murthy KGK, Salzman AL, Southan GJ and Szabó C: Diabetic endothelial dysfunction: the role of poly(ADP-ribose) polymerase activation. Nat Med 7: 108-113, 2001. 
13. Jagtap P, Soriano FG, Virag L, Liaudet L, Mabley J, Szabo E, Hasko G, Marton A, Lorigados CB, Gallyas F Jr, Sumegi B, Hoyt DG, Baloglu E, VanDuzer J, Salzman AL, Southan GJ and Szabo C: Novel phenanthridinone inhibitors of poly(adenosine 5'-diphosphate-ribose) synthetase: potent cytoprotective and antishock agents. Crit Care Med 30: 1071-1082, 2002.

14. Pacher P, Liaudet L, Soriano FG, Mabley JG, Szabo E and Szabo C: The role of poly(ADP-ribose) polymerase activation in the development of myocardial and endothelial dysfunction in diabetes. Diabetes 51: 514-521, 2002.

15. Cuzzocrea S, Zingarelli B, O'Connor M, Salzman AL and Szabo C: Effect of L-buthionine-(S,R)-sulphoximine, an inhibitor of $\gamma$ glutamylcysteine synthetase on peroxynitrite- and endotoxic shock-induced vascular failure. Br J Pharmacol 123: 525-537, 1998.

16. Lizard G, Deckert V, Dubrez L, Moisant M, Gambert P and Lagrost L: Induction of apoptosis in endothelial cells treated with cholesterol oxides. Am J Pathol 148: 1625-1638, 1996.

17. Lizard G, Monier S, Cordelet C, Gesquiere L, Deckert V, Gueldry S, Lagrost L and Gambert P: Characterization and comparison of the mode of cell death, apoptosis versus necrosis, induced by 7 beta-hydroxycholesterol and 7-ketocholesterol in the cells of the vascular wall. Arterioscler Thromb Vasc Biol 19: 1190-1200, 1999.

18. Yin J, Chaufour X, McLachlan C, McGuire M, White G, King N and Hambly B: Apoptosis of vascular smooth muscle cells induced by cholesterol and its oxides in vitro and in vivo. Atherosclerosis 148: 365-374, 2000.

19. Mougenot N, Lesnik P, Ramirez-Gil JF, Nataf P, Diczfalusy U, Chapman MJ and Lechat P: Effect of the oxidation state of LDL on the modulation of arterial vasomotor response in vitro. Atherosclerosis 133: 183-192, 1997.

20. Szabó C: DNA strand breakage and activation of poly-ADP ribosyltransferase: a cytotoxic pathway triggered by peroxynitrite. Free Radic Biol Med 21: 855-869, 1996.
21. Szabó C: The role of peroxynitrite in the pathophysiology of shock, infammation and ischaemia-reperfusion injury. Shock 6 : 79-88, 1996.

22. Millanvoye-Van Brussel E, Topal G, Brunet A, Do Pham T, Deckert V, Rendu F and David-Dufilho M: Lysophosphatidylcholine and 7-oxocholesterol modulate $\mathrm{Ca}^{2+}$ signals and inhibit the phosphorylation of endothelial NO synthase and cytosolic phospholipase A2. Biochem J 380: 533-539, 2004.

23. Lee CS, Joe EH and Jou I: Oxysterols suppress inducible nitric oxide synthase expression in lipopolysaccharide-stimulated astrocytes through liver X receptor. Neuroreport 17: 183-187, 2006.

24. Lyons MA, Samman S, Gatto L and Brown AJ: Rapid hepatic metabolism of 7-ketocholesterol in vivo: implications for dietary oxysterols. J Lipid Res 40: 1846-1857, 1999.

25. Lyons MA and Brown AJ: Ketocholesterol delivered to mice in chylomicron remnant-like particles is rapidly metabolised, excreted and does not accumulate in aorta. Biochim Biophys Acta 1530: 209-218, 2001.

26. Martinet W, De Bie M, Schrijvers DM, De Meyer GR, Herman AG and Kockxn MM: 7-ketocholesterol induces protein ubiquitination, myelin figure formation, and light chain 3 processing in vascular smooth muscle cells. Arterioscler Thromb Vasc Biol 24: 2296-2301, 2004

27. Berthier A, Lemaire-Ewing S, Prunet C, Montange T, Vejux A, Pais de Barros JP, Monier S, Gambert P, Lizard G and Neel D: 7-Ketocholesterol-induced apoptosis. Involvement of several pro-apoptotic but also anti-apoptotic calcium-dependent transduction pathways. FEBS J 272: 3093-3104, 2005.

28. Pedruzzi E, Guichard C, Ollivier V, Driss F, Fay M, Prunet C, Marie JC, Pouzet C, Samadi M, Elbim C, O'Dowd Y, Bens M, Vandewalle A, Gougerot-Pocidalo MA, Lizard G and Ogier-Denis E: NAD(P)H oxidase Nox-4 mediates 7ketocholesterol-induced endoplasmic reticulum stress and apoptosis in human aortic smooth muscle cells. Mol Cell Biol 24: 10703-10717, 2004 